\title{
Determinants of the Adoption of Climate-Smart Agricultural Practices in Siyadebrina Wayu District, North Shewa, Ethiopia
}

\author{
Tekeste Kifle $^{1^{*}} \quad$ Desalegn Yayeh $^{2}$ Messay Mulugeta ${ }^{3}$ \\ 1. Ethiopian Institute of Agricultural Research (EIAR), PhD Candidate in Food Security and Development, \\ Center for Food Security Studies, College of Development Studies, Addis Ababa University, Addis Ababa, \\ Ethiopia \\ 2. Assistant Professor, Center for Food Security Studies, College of Development Studies, Addis Ababa \\ University, Addis Ababa, Ethiopia \\ 3. Associate Professor, Center for Food Security Studies, College of Development Studies, Addis Ababa \\ University, Addis Ababa, Ethiopia
}

\begin{abstract}
Climate-Smart Agriculture (CSA) is one of the solutions that simultaneously address the issues of food security, climate change and agricultural productivity. Climate-smart agricultural (CSA) practices have the potential of its triple potential benefits of improved productivity and high income, reduction or removal of greenhouse gases and improved household food security. The objective of this study was to examine the determinants of adoption of climate smart agricultural practices. The methodology of the study was conducted using mixed methods approaches, in which 368 randomly selected households were surveyed, 10 key informants were interviewed, and 6 focus group discussions participants were held. The analysis was based on survey data and a binary logistic regression model was used. Findings revealed that highly adopted CSA practices in the study area were integrated soil fertility management, conservation agriculture, small scale irrigation, and improved livestock feed. Factors influencing adoption of CSA practices were also explored such as household size, farming system, off-farm income, access to irrigated farm, distance to market, farm size, and access to agricultural credit. The study concludes that a large proportion of respondents were aware of most of the practices, but adoption of CSA practices examined was very low. Therefore, as a recommendation sensitization of farmers on reality of climate change and the need to adopt CSA practices towards reduction of adverse effect of climate change should continue. Policy and support program should focus on dissemination of CSA practices to a larger proportion of smallholder farmers.
\end{abstract}

Keywords: Climate Smart Agriculture, Adoption, Determinants, Food security, Ethiopia

DOI: $10.7176 / \mathrm{JAAS} / 68-08$

Publication date:September $30^{\text {th }} 2020$

\section{Introduction}

Agriculture is the backbone of the Ethiopian economy. This particular sector determines the growth of all other sectors and consequently, the whole national economy. On average, crop production makes up 60 percent of the sector's outputs, whereas livestock accounts for 27 percent and other areas contribute 13 percent of the total agricultural value added. The sector is dominated by small-scale farmers who practice rain-fed mixed farming by employing traditional technology, adopting a low input and low output production system. The land tilled by the Ethiopian small-scale farmer accounts for 95 percent of the total area under agricultural use and these farmers are responsible for more than 90 percent of the total agricultural output. Agriculture accounted for $49 \%$ of GDP, $85 \%$ of exports, and $85 \%$ of employment (UNDP 2016).

The climate-related shocks in agricultural production that farmers have to deal with have pushed the need for resilience in agriculture to the forefront of agricultural policies across the world (Vera et al. 2017). There is a growing interest among policymakers and development practitioners to get as many farmers, mainly small-scale farmers, as possible to embrace sustainable farming practices that will fortify agricultural and food systems.

Climate change, to a great extent, has been the outcome of the accumulation of greenhouse gas (GHG), which is caused by human activities (Vermeulen 2014). Agricultural activities such as bush burning and deforestation are part of the human activities contributing to GHG emission $[3,4]$. Climate change has globally influenced natural and social systems (IPCC 2014). However, studies have shown that developing countries, particularly African countries, are more vulnerable to the impacts of climate change (Lamboll et al. 2017). The small-scale farming system in African countries is predominantly rain-fed, thereby making it highly susceptible to climate change and variability (Tibesigwa et al. 2015).

Climate smart agriculture (CSA) is an approach to guide the management of agriculture in the era of climate change. CSA aims to provide globally applicable principles on managing agriculture for food security under climate change that could provide a basis for policy support and recommendations by multilateral organizations, such as UN's FAO. The major features of the CSA approach were developed in response to limitations in the international climate policy arena in the understanding of agriculture's role in food security and its potential for capturing synergies between adaptation and mitigation (Lipper and Zilberman 2018). 
A study conducted by (Melaku et al. 2016) at country level in Ethiopia has identified that the adoption rate of CSA practices is low. To support the facilitation for adoption, different key opportunities and challenges were identified and strategic measures were recommended. The study also indicated that there is a gap in research at local level regarding CSA considering the bio-physical, socio-economic and developmental context. These situations ask the need to conduct research at local context in order to strengthen the evidence based decisions for adoption and dissemination of improved technologies. Hence, there were insufficient empirical studies based on determinants of the adoption of climate smart agriculture practices in the study area. This paper aims to bridge the information gap on CSA adoption in small-scale agriculture by assessing the factors affecting the level of adoption of CSA practices by small-scale farmers, in Siyadebrina Wayu district, Ethiopia.

\section{Materials and Methods \\ Description of the Study Area}

The study was carried out in smallholder farmers Amhara National Regional State (ANRS) of Ethiopia, North Shewa zone, Siyadebrina Wayu district. It is far about $175 \mathrm{~km}$ away from Addis Ababa, and located in between $9^{0} 42^{\prime}$ to $9^{0} 53^{\prime} \mathrm{N}$ latitude and $39^{\circ} 08^{\prime}$ to $39^{\circ} 17^{\prime}$ E longitude (CSA 2007). The district has 13 rural kebeles and one urban center (Deneba town). Based on CSA (2013) population projection of Ethiopia for all regions at district level, in 2017 this district has a total population 73,166 of whom 37,397 are males; 35,769 are females; and 7,884 are urban inhabitants. The farming system is characterized by a smallholder mixed agriculture for which crop and livestock are the most important livelihood assets.

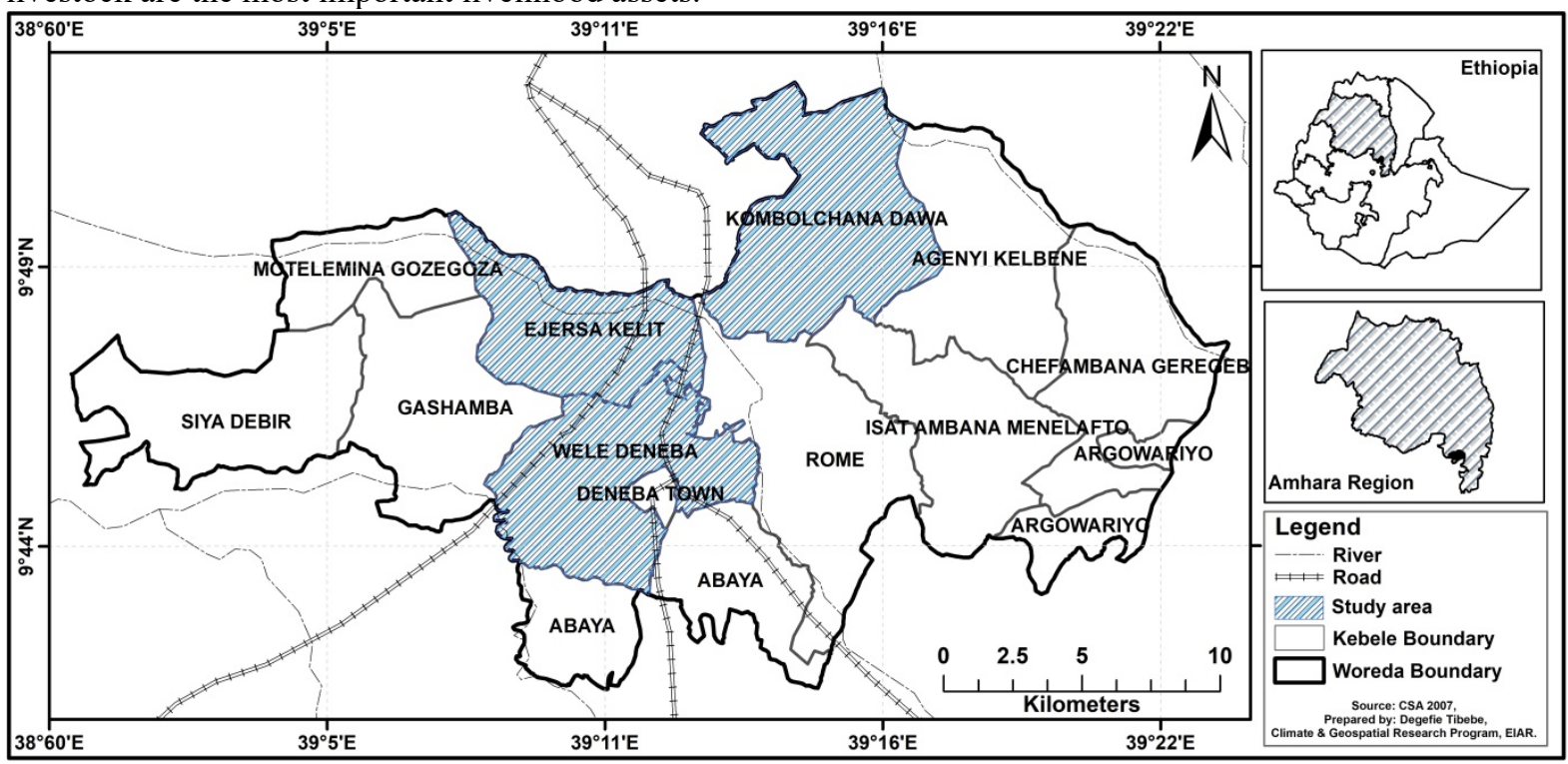

Figure 1: Map of Siyadebrina Wayu district

\section{Research Approach and Sampling Design}

This study was followed a mixed approach (quantitative and qualitative) to triangulate the interpretation of data and results to enhance the reliability and validity of findings. The cross-sectional research design was considered appropriately for applied in this research because it enables rational and sound conclusions, coupled with its time and cost efficiency. A multi-stage sampling procedure was used for the selection of the location in which units of observation have the required characteristics.

The multi-stage sampling technique involved the purposive selection of the district and the three targeted study kebeles based on their crop and livestock production potential area to show the climate change variability and effect of CSA practices on food security. These kebeles are Ejersa Kubeti, Wele Deneba, and Kombolchana Dawa. The sampling frame was 4,569 in the three kebeles. Yamane (1967) provides a simplified formula to calculate the sample size. Then, we apply it and determine the number of sample households to be about 368 . The respondents were selected by simple random sampling method.

$\mathrm{n}=\frac{N}{1+N(e) 2}$

Where, $\mathrm{n}$ is the sample size, $\mathrm{N}$ is the population size, and $\mathrm{e}$ is the desired level of precision.

\section{Data Sources and Collection Methods}

The study used both quantitative and qualitative data generated from primary and secondary data sources. The 
primary data were obtained from the original sources that are household respondents. Primary information were gathered by using different approaches, that includes a household survey, an interview with key informants, focused group discussion and field observations. Secondary data were collected from existing sources that are, intensive desk review of published and unpublished literatures such as peer reviewed journals, books, conference paper, dissertations and research reports.

Reliability and validity of the instruments and methodology deal with the quality of data and appropriateness of the methods used. Comprehensive and realistic numerical data, ideas, viewpoints, concepts, definitions, arguments and suggestions were collected so as to enhance the analytical frameworks, and come up with profound research outputs and thoughtful recommendations. While collecting the data, ethical considerations were seriously taken into account to ensure the protection of concern, integrity, anonymity, consents and other human elements of the informants.

\section{Methods of Data analysis}

Data obtained from primary and secondary sources were analyzed using descriptive statistical methods which include frequency distribution, percentage, mean, standard deviation and cross-tabulation and used to summarize and presents demographic, socio-economic and institutional factors. A binary logistic regression model was used to analyze the cross sectional data, to perform all the required hypothesis tests and the determinants of the level of adoption of climate smart agriculture practices by using SPSS version 23 software.

Binary logistic regression is the form of regression used when the dependent variable is a dichotomous and the predictor variables are of any type (Spicer 2004). The model specification is a generalized linear model and can be written as:

$\operatorname{Logit}\left(\pi\left(\mathrm{x}_{\mathrm{i}}\right)\right)=\log \left(\pi\left(\mathrm{x}_{\mathrm{i}}\right) / 1-\pi\left(\mathrm{x}_{\mathrm{i}}\right)\right)=\beta_{0}+\beta_{1} \mathrm{x}_{1 \mathrm{i}}+\ldots+\beta_{\mathrm{p}} \mathrm{x}_{\mathrm{pi}}$ or

$\ln (\mathrm{p} / 1-\mathrm{p})=\beta_{0}+\beta_{1} \mathrm{x}_{1}+\beta_{2} \mathrm{x}_{2}+\ldots+\beta_{\mathrm{p}} \mathrm{x}_{\mathrm{p}}$

Where, $\mathrm{p}=$ probability of event occurring, $\mathrm{p} / 1-\mathrm{p}=$ odds ratio

In this study the response (dependent variable) Y represents the adoption of CSA practices. Farmers perceived that the adopted CSA practices contributed to both farm income and household food availability. It is measured as a dummy variable, a numeric value 1 if number of farmers adopts CSA, and 0 if no adopters. The explanatory (independent variables) in the regression model are hypothesized to affect the smallholder farmers' adoption of CSA practices and combined effects of various factors such as household demographic characteristics, socioeconomic characteristics, and institutional characteristics. Based on the review of related literatures, and past research findings, fourteen potential explanatory variables (sex of the household head $(\mathrm{HH})$, age of the $\mathrm{HH}$, household size, education, farm size, farming experience, farming system, access to irrigation, farm income, offfarm income, access to credit, distance to market, and access to weather information) were considered in this study and examined the determinants of the level of adoption of climate smart agricultural practices.

\section{Results and Discussion}

\section{Socio-economic and Demographic Characteristics of the Households}

The socio-economic and demographic status of households in three kebeles was presented in Table 1. In this study, out of the 368 respondents in both kebele 35 (9.5\%) were female-headed and $333(90.5 \%)$ male-headed households. Therefore, male-headed households were in a better position to pull more labor force than the female-headed ones and they also made decisions on farming activities. Age determine CSA practices and adoption rate among the farming households. Accordingly the respondents, age was classified based on the Santrock (2011) age group classification from 20-40 young, 41-60 adult and >60 are elders. In this regard the age distribution of the respondents ranged from 21- 65 years and the average age was 44 years. However, over $90 \%$ of the respondents were still in active age group between 20-60 years. So, productive age groups are higher than the non-productive age groups, the probability of a household to be in shortage of food would be less, provided that the area provides good working atmosphere and production potential.

The average household size of the respondents is 5 and the absolute size of the respondents ranged from 112 members. The marital status of the household head showed that over $80 \%$ of the respondents was married and in terms of religious composition over $90 \%$ was Orthodox Christianity. The educational level showed that $55.4 \%$ of the respondents from both kebeles had never attained any level of education, $44.3 \%$ of the respondents have attained primary and secondary school and almost $0.3 \%$ has attended Technical, Vocational and Educational Training (TVET) \& above. Thus, this indicates that most of smallholder farmers have appreciable formal knowledge to understand and implement climate-smart agricultural technologies promoted in the area as compared to illiterate ones. The educational level of farmers has a direct link with the perception to climate variability. Farmers with relatively higher education levels have opportunities to get information from schools, environmental clubs and other sources of information. Thus farmers with higher educational level have better perception than farmers with lower levels of education.

The data collected from both kebeles indicated that about $50.5 \%$ of the respondents had $>1.5$ ha of farmland 
and $59.5 \%$ of the respondents have $>20$ years in farm experience in the study area. The average farm experience of the respondents is 23 years and the experience ranged from $2-45$ years. The result also showed that $56 \%$ of the respondents were obtained access to credit service from various sources. Access to credit services enhances the probability of a smallholder farmer to adopt CSA practices that improve food security and income. This result related with the findings of Amao and Ayantoye (2015), who proved that access to credit, can be used to expand farm production through creating the financial capacity to purchase and use of modern improved agricultural inputs.

About $75.5 \%$ of the respondents had access to weather information and $67 \%$ of the respondents have low climate change information in the study area. According to Kalungu et al, (2013) farmers' perception on climate changes and its impacts on the agricultural production have resulted in the adjustment of agricultural calendar and adoption of different adaptation strategies. The perception of household's climate change information influenced different economic and livelihood attributes. Reducing of crop production and livestock, drought, high temperature, high or low rain fall, food insecurity, disturbance of eco-system, crop pests and diseases, lack of awareness on agricultural practices and increase land degradation were factors that influencing the climate change in the study area.

Table 1: Socio-economic and Demographic Status of three rural kebeles

\begin{tabular}{|c|c|c|c|c|c|c|}
\hline \multirow[b]{2}{*}{ Variables } & \multirow[b]{2}{*}{ Category } & \multicolumn{3}{|c|}{ Kebeles } & \multirow[b]{2}{*}{ Total } & \multirow[b]{2}{*}{$\%$} \\
\hline & & $\begin{array}{l}\text { Ejersa } \\
\text { Kubeti }\end{array}$ & $\begin{array}{c}\text { Kombolcha } \\
\text { Dawa }\end{array}$ & $\begin{array}{c}\text { Wele } \\
\text { Deneba }\end{array}$ & & \\
\hline \multirow[t]{2}{*}{ Sex } & Male & 62 & 142 & 129 & 333 & 90.5 \\
\hline & Female & 6 & 13 & 16 & 35 & 9.5 \\
\hline \multirow[t]{3}{*}{ Age } & $20-40$ & & & & 144 & 39.1 \\
\hline & $41-60$ & & & & 195 & 53 \\
\hline & $>60$ & & & & 29 & 7.9 \\
\hline \multirow[t]{2}{*}{ Household size } & Male & 191 & 423 & 414 & 1028 & 54.5 \\
\hline & Female & 140 & 352 & 366 & 858 & 45.5 \\
\hline \multirow[t]{4}{*}{ Marital status } & Single & 1 & 7 & 10 & 18 & 4.9 \\
\hline & Married & 61 & 143 & 124 & 328 & 89.1 \\
\hline & Divorced & 1 & 1 & 0 & 2 & 0.6 \\
\hline & Widowed & 5 & 4 & 11 & 20 & 5.4 \\
\hline \multirow[t]{5}{*}{ Educational level } & Illiterate & 39 & 79 & 86 & 204 & 55.4 \\
\hline & Grade $1-4$ & 23 & 42 & 34 & 99 & 26.9 \\
\hline & Grade 5-8 & 3 & 22 & 17 & 42 & 11.4 \\
\hline & Grade 9-12 & 3 & 11 & 8 & 22 & 6 \\
\hline & TVET \& above & 0 & 1 & 0 & 1 & 0.3 \\
\hline \multirow[t]{3}{*}{ Farm Size (Ha.) } & $0.25-1$ & 8 & 48 & 34 & 90 & 24.46 \\
\hline & $1.01-1.5$ & 16 & 43 & 33 & 92 & 25 \\
\hline & $>1.5$ & 44 & 64 & 78 & 186 & 50.54 \\
\hline \multirow[t]{3}{*}{ Farm Experience } & $1-10$ & 5 & 19 & 17 & 41 & 11.14 \\
\hline & $11-20$ & 26 & 43 & 39 & 108 & 29.35 \\
\hline & $>20$ & 37 & 93 & 89 & 219 & 59.51 \\
\hline \multirow[t]{2}{*}{ Access to credit service } & Yes & & & & 206 & 56 \\
\hline & No & & & & 162 & 44 \\
\hline \multirow{2}{*}{$\begin{array}{l}\text { Access to weather } \\
\text { information }\end{array}$} & Yes & & & & 278 & 75.5 \\
\hline & No & & & & 90 & 24.5 \\
\hline \multirow{3}{*}{$\begin{array}{l}\text { Climate change } \\
\text { information }\end{array}$} & Low & & & & 247 & 67 \\
\hline & Medium & & & & 118 & 32 \\
\hline & High & & & & 3 & 1 \\
\hline
\end{tabular}

Source: Field survey data, 2019 


\section{Climate smart agriculture practices in the study area}

Data analyzed using descriptive statistics to identify local climate smart agriculture practices in the study area including mean and percentage. According to Saguye (2017) the following criteria were used to rank the rate of adoption based on the percentage of the respondents in the total sample. Adoption rate greater than $70 \%$ very high, 60 to $70 \%$ high, 50 to $59 \%$ fairly high, 40 to $49 \%$ fairly low, and below $40 \%$ very low. According to Branca et al. (2013), FAO (2016) and Saguye (2017) the following climate smart agricultural practices were categorized: agronomic practices are (improved seed varieties, crop rotation, intercropping, and cover crop); integrated soil fertility management (composting, organic fertilizer and efficient use of inorganic fertilizer); conservation agriculture (tillage and residue management); irrigation (water management, bunds, terracing, contouring, and water harvesting); integrated pest management (blend of cultural, biological and chemical control); agro-forestry (intercropping crops and trees, live fencing); post-harvest management (harvesting, cleaning or disinfecting, storage); improved livestock feed (grazing, feed improvement, breed improvement).

Climate smart agriculture practices adopted by farmers in the study area presented in Table 2 . The results of the study revealed that CSA practices such as fertilizer application techniques (89.4\%); livestock breed improvement and diversification (63.1\%) improved crop varieties $(75.3 \%)$; crop rotation or intercropping with cereals and legumes (71.7\%); pest resistance, high yielding, and drought and heat tolerant crops $(77.5 \%)$ were highly adopted. Post-harvest technology practices (58.7\%) also fairly adopted while other components of CSA practices conservation tillage (25.5\%), crop residue management (41.1\%), mulching $(13.1 \%)$, compost and manure management $(27.7 \%)$, water management $(8.4 \%)$, water harvesting $(9.5 \%)$, improved livestock feed and feeding practices $(37.2 \%)$, and agro-forestry $(32.9 \%)$ were low. Generally farmers' adoption rates of the climate smart agricultural practices in the study area were very low. Key informants and Focus group reported that feed shortage occurs during the period between February to May and conservation feeding is one of the feeding strategy used to reduce the shortage during this time. Conservation and concentrate feeding is common and adopted practice by most farmers mainly during feed shortage. This finding is in line with CSA (2017) reported that identified livestock feed resources in Ethiopia are mainly obtained from natural and improved pastures, feed conservation (hay making, silage making, and crop residue), forage crops, agro-industrial by-products and non-conventional feeds.

Therefore, based on this analysis, the local CSA practices were identified such as crop rotation; fertilizer application; popularization of new technology crop varieties; using pest resistance, high yielding, tolerant to drought \& short season varieties; breed improvement and post- harvest technologies are highly adopted in the study area.

In a similar way, Aweke (2017) finds adoption levels of some CSA practices and technologies, such as conservation agriculture and agroforestry, among smallholder farmers remain low. FAO (2016) also indicated in the broader Ethiopian context, CSA practices and technologies are being implemented within the framework of integrated watershed management, which incorporates a broad range of practices in crop and livestock production including agroforestry, crop rotation and intercropping, soil and water conservation. In terms of adoption, most of the CSA practices and technologies identified have low to medium on-farm adoption rates, despite their potential benefits to adaptation, productivity increase and mitigation efforts. 
Table 2: Climate smart agriculture practices adopted by farmers in the study area

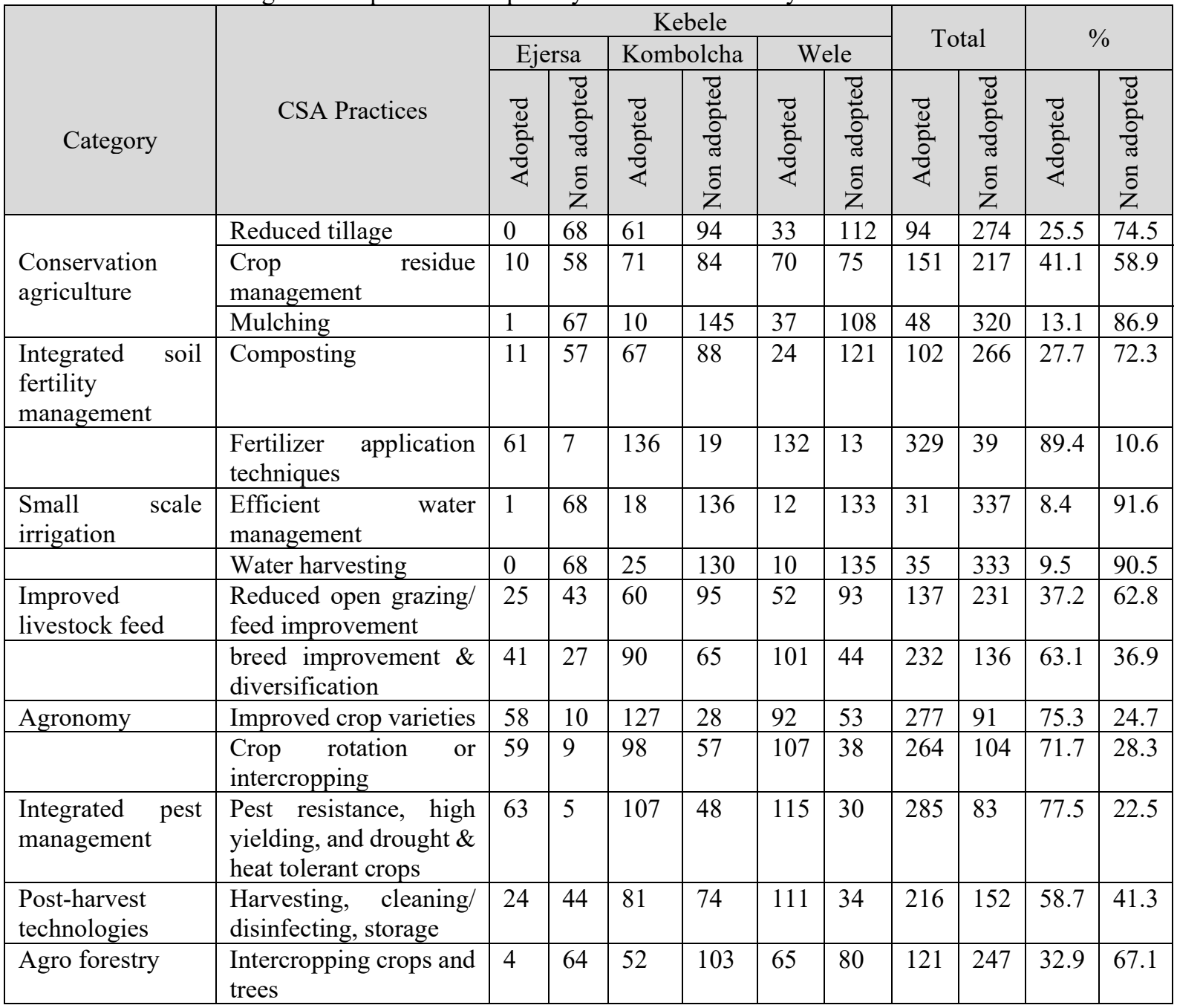

Source: Field survey data, 2019

\section{Factors influencing the level of adoption of Climate Smart Agriculture Practices}

The results of binary logistic regression model as shown in Table 3, four variables (household size, farming system, farm income source and off-farm income) are statistically significant ( $\mathrm{p} \leq 0.05)$ and influencing the adoption of conservation agriculture. A farm income source is a factor that adversely affects adoption of conservation agriculture, while household size, farming system, and off-farm income have positive relationship. Regarding adoption of integrated soil fertility management farm income source and off-farm income are statistically significant variables at $(\mathrm{p}=0.028$, and 0.034 level) respectively. A farm income source is factors that adversely affect integrated soil fertility management, while off-farm income has positive relationship. In another case, factors that affect the adoption of small scale irrigation are farm size, access to irrigation, and distance to market and they are statistically significant at $(\mathrm{p}=0.015,0.000$, and 0.000 level) respectively. A farm size is a factor that adversely affects adoption of small scale irrigation, while access to irrigation and distance to market variables has positive relationship. Factors that influence adoption of improved livestock feed are farm size, offfarm income, access to agricultural credit, and access to extension services, and they are statistically significant at $(p=0.035,0.000,0.020$, and 0.021 level) respectively. Off-farm income and access to extension service are factors that adversely affect the adoption of improved livestock feed, while farm size and access to agricultural credit have positive relationship, and significantly enhance the adoption of improved livestock feed.

In summary, the major factors that influence the adoption of CSA practices were identified in this study. The results showed that there were significant differences with regards to explanatory variables such as household size, farming system, farm income source, off-farm income, farm size, access to irrigated farm, distance to market, access to extension service, and access to agricultural credit. Factors such as household size, farming system, offfarm income, access to irrigated farm, distance to market, farm size, and access to agricultural credit have positive relationship; and farm income source, off-farm income, and access to extension service have negative relationship. 
Therefore, crop \& livestock production would have higher productivity that factors of household size, farming system, off-farm income, access to irrigated farm, distance to market, farm size, and access to agricultural credit are more likely to adopt climate smart agriculture practices and its implication to food security in the study area. Table 3: Factors influencing adoption of Climate Smart Agriculture practices in the study area

\begin{tabular}{|c|c|c|c|}
\hline \multicolumn{4}{|c|}{ Adoption of Conservation Agriculture } \\
\hline Independent Variables & Coefficient & S.E. & Sig. \\
\hline Sex of the household head & -0.289 & 0.443 & 0.514 \\
\hline Age of the household head & -0.014 & 0.013 & 0.288 \\
\hline Household size & 0.185 & 0.073 & $0.012 *$ \\
\hline Farm size & -0.169 & 0.183 & 0.358 \\
\hline Farming system & 2.527 & 0.408 & $0.000 * * *$ \\
\hline Access to Irrigation & -0.741 & 0.744 & 0.319 \\
\hline Farm Income sources & -1.089 & 0.315 & $0.001 * * *$ \\
\hline Off-farm Income & 0.871 & 0.440 & $0.048 * *$ \\
\hline Access to extension service & -0.645 & 0.789 & 0.414 \\
\hline Distance to market & -0.045 & 0.038 & 0.241 \\
\hline Access to weather information & -0.249 & 0.302 & 0.409 \\
\hline Constant & 1.297 & 1.104 & 0.240 \\
\hline \multicolumn{4}{|c|}{ Adoption of Integrated Soil Fertility Management } \\
\hline Age of the household head & -0.037 & $\mathbf{0 . 0 3 9}$ & 0.341 \\
\hline Household size & -0.050 & 0.068 & 0.462 \\
\hline Farm size & 0.102 & 0.174 & 0.559 \\
\hline Farming experience & 0.040 & 0.042 & 0.335 \\
\hline Farming system & -0.531 & 0.350 & 0.130 \\
\hline Farm income sources & -0.649 & 0.296 & $0.028 * *$ \\
\hline Off-farm income & 0.857 & 0.405 & $0.034 * *$ \\
\hline Distance to market & -0.025 & 0.034 & 0.474 \\
\hline Constant & 0.455 & 0.889 & 0.609 \\
\hline \multicolumn{4}{|c|}{ Adoption of Small scale Irrigation } \\
\hline Sex of the household head & 1.031 & 0.795 & 0.194 \\
\hline Farm size & -0.698 & 0.285 & $0.015^{*}$ \\
\hline Access to irrigation & 4.970 & 1.122 & $0.000 * * *$ \\
\hline Farm income sources & -0.815 & 0.446 & 0.068 \\
\hline Access to agricultural credit & -0.267 & 0.383 & 0.485 \\
\hline Distance to market & 0.185 & 0.045 & $0.000 * * *$ \\
\hline Acc. to weather information & -0.535 & 0.451 & 0.235 \\
\hline Constant & -2.191 & 0.961 & 0.023 \\
\hline \multicolumn{4}{|c|}{ Adoption of Improved Livestock Feed } \\
\hline Sex of the household head & -0.470 & 0.414 & 0.255 \\
\hline Age of the household head & 0.065 & 0.039 & 0.095 \\
\hline Farm size & 0.364 & 0.173 & $0.035 * *$ \\
\hline Farming experience & -0.079 & 0.042 & 0.064 \\
\hline Access to irrigation & -0.661 & 0.591 & 0.263 \\
\hline Farm income sources & 0.552 & 0.297 & 0.063 \\
\hline Off-farm income & -2.983 & 0.639 & $0.000 * * *$ \\
\hline Access to agricultural credit & 0.550 & 0.237 & $0.020 * *$ \\
\hline Access to extension service & -3.035 & 1.313 & $0.021 * *$ \\
\hline Acc. to weather information & 0.341 & 0.275 & 0.215 \\
\hline Constant & 1.427 & 1.615 & 0.377 \\
\hline
\end{tabular}

Source: Field survey data, 2019

\section{Conclusion}

Few studies have been conducted to analyze the factors influencing the level of CSA adoption among small-scale farmers. The adoption of CSA practices, despite the benefits, is not automatic among small-scale farmers, hence the need to investigate the factors influencing CSA adoption in the small-scale farming system. The study examined the 
extent of farmers' adoption of climate smart agricultural practices as baseline for intervention on climate mitigation measures. The results indicate that a large proportion of respondents were aware of most of the practices, but adoption of most of the practices examined was very low. Local CSA practices such as crop rotation and intercropping; efficient fertilizer application techniques; popularization of new crops and improved crop varieties; pest resistance, high yielding, and drought tolerant crops were highly adopted while adoption of other components of CSA practices were very low.

The result shows the determining factors of adoption of climate smart agriculture practices in the study area. Those factors are household size, farming system, farm income source, off-farm income, farm size, access to irrigated farm, distance to market, access to extension service, access to weather information, and access to agricultural credit.

The results of this study are of critical significance to the government, organizations and other stakeholders in Ethiopia with interest in the agricultural sector and in mitigating GHG emissions. The findings from this study have implications for further research and policy design and implementation.

Sensitization campaign on reality of climate change and the need to adopt climate smart agriculture practices towards reduction of adverse effect of climate change should be intensified. Disseminate extensively accurate information on CSA practices to cover a larger proportion of smallholder farmers in the study area.

CSA needs to be mainstreamed into core government strategies, guidelines, manuals and annual action plans. In this regard the experience of the SLM program is a good lesson for integrating CSA technologies into project and program implementation manuals. The government should be given priority to CSA practices that bring productivity gains, enhance resilience and reduce emissions.

Farmers should be encouraged to join farmer social groups, which would expose them to agricultural innovations. Also, the farmers should be well educated and enlightened by extension services on the benefits of CSA practices in agricultural production, which are reducing the negative impact of climate change on their farming activities.

Research, Policy and supportive programs should focus on adoption of climate smart agriculture practices especially those ones that were not highly adopted by farmers and strengthen and encourage adoption of the priority climate smart agriculture practices.

\section{Abbreviations}

ANRS: Amhara National Regional State; CSAp: Climate Smart Agriculture practices; CSA: Central Statistics Agency; FAO: Food and Agricultural Organization; FGD: Focus Group Discussions; GDP: Gross Domestic Product; HHs: Households; KII: Key Informant Interview; SLMP: Sustainable Land Management Program; SPSS: Statistical Package for Social Science; TVET: Technical and Vocational Education Training; UN: United Nation; UNDP: United Nations Development Program

\section{References}

Amadou Z, Tabbo AM, Danbaky AB (2015) Evaluating farmers' adaptation strategies to climate change: A case study of Kaou local government area, Tahoua State, Niger Republic. Doi: 10.4102

Amao JO, Ayantoye K (2015) Correlates of Food Insecurity Transition and its Determinants among Farming Households in North Central, Nigeria. Journal of Economics and Sustainable Development 6(24): pp. 230244.

Aweke M (2017) Climate Smart Agriculture in Ethiopia. Climate Smart Agriculture Country Profiles for Africa Series. January 2017

Branca G, McCarthy N, Lipper L, Jolejole MC (2013) Food security, climate change and sustainable land management: a review. Agronomy for Sustainable Development 33(4): pp. 635-650. FAO of the United Nations.

CSA (2007) Central Statistical Authority Statistical Tables for the 2007 Population and Housing Census of Ethiopia. Central Statistical Agency, Addis Ababa, Ethiopia.

CSA (2013) Population Projection of Ethiopia for All Regions at Woreda Level from 2014-2017. Federal Democratic Republic of Ethiopia, Addis Ababa.

CSA (2017) Agricultural Sample Surveys 2017/2018 (2010 E.C.), Volume 1. Report on area \& production of major crops. Federal Democratic Republic of Ethiopia, Addis Ababa.

FAO (2013) Climate-Smart Agriculture, Source Book. Food and Agricultural Organization of the United Nations, Rome

FAO (2016) Ethiopia Climate-Smart Agriculture Scoping Study. United Nations, Addis Ababa, Ethiopia.

Hosmer DW, Lemeshow S (2001) Applied Logistic Regression, Second Edition. ISBN: 9780471356325, September 2001

IPCC (2014) Climate Change 2014: Impacts, Adaptation, and Vulnerability, part B regional aspects. In Working Group II Contribution to the Fifth Assessment Report of the Intergovernmental Panel on Climate Change; 
Cambridge University Press: New York, NY, USA.

Lamboll R, Stathers T, Morton J (2017) Climate Change and Agricultural Systems. In Agricultural Systems, $2^{\text {nd }}$ ed.; Academic Press: Cambridge, MA, USA: pp. 441-490.

Lipper L, Zilberman D (2018) A Short History of the Evolution of the Climate Smart Agriculture Approach and Its Links to Climate Change and Sustainable Agriculture.

Melaku J, Sebastian G, Edward K (2016) Ethiopia Climate Smart Agriculture Scoping Study. FAO, Addis Ababa.

Oates KS (2015) A logistic regression analysis of score sending and college matching among high school students. PhD dissertation, University of Iowa. Doi.10.17077

Pallant J (2007) SPSS Survival Manual, New York, New York: Open University Press.

Saguye TS (2017) Assessment of Farmers ${ }^{\text {ee }}$ Perception of Climate Change and Variability and its Implication for Implementation of Climate-Smart Agricultural Practices. Journal of Geography \& Natural Disasters, 7(191): pp. 1-9.

Santrock JW (2011) Life-Span Development (13 ${ }^{\text {th }}$ Ed.). New York: McGraw-Hill.

Spicer J (2004) Making sense of multivariate data analysis. Sage Publications, California, 123-151

Tibesigwa B, Visser M, Turpie J (2015) The impact of climate change on net revenue and food adequacy of subsistence farming households in South Africa. Environ. Dev. Econ. (20): 327-353.

UNDP (2016) Strengthening National Capacities to Enhance Agricultural Production and Productivity. United Nations Development Program.

Vera TS, Wiliams CE, Justin CO (2017) Understanding the factors affecting adoption of sub packages of CSA in Southern Malawi. Int. J. Agric. Econ. Ext. 2017, 5, 259-265.

Vermeulen SJ (2014) Climate change, food security and small-scale producers: Analysis of findings of the Fifth Assessment Report (AR5) of the Intergovernmental Panel on Climate Change (IPCC). Copenhagen, Denmark. Yamane T (1967) Statistics: An Introductory Analysis, 2nd Ed., New York: Harper and Row 